\title{
Assistance architecture and health: discussion on concepts and actors
}

\author{
Cybelle S. Miranda, Marcia R. Monteiro
}

\section{Cybelle S. Miranda}

Doctor in Anthropology, professor at Programa de Pós-graduação em Arquitetura e Urbanismo - UFPA; cybelle1974@hotmail.com

\section{Marcia R. Monteiro}

Doctor in Human Sciences, professor at Faculdade de Arquitetura e Urbanismo - UFAL; mrmontei@hotmail.com

\begin{abstract}
Inscribed in the body of research on the health architecture, the definition of conceptions of architecture, fulfilling the role of 'aid' proposed under the sign of charity, philanthropy and service, is at the heart of this paper. It's proposed to highlight the architectural design, considering the intertwining of these two fields of knowledge: architecture and health, the historical trajectory of hospitals, either in physical and functional aspects, aesthetic, medical and scientific, technological, geographical, socio-cultural, political or economic. We should also understand the Assistance Architecture in the context of its funders and designers, be they monarchs, architects, doctors, patrons, philanthropists and institutions, accentuating the transits between Brazil and Portugal in the nineteenth and twentieth centuries and dialogue with researchers from other territorial domains. This paper, which presents the results of IV ENANPARQ Session, is part of the Research Group "Health and City: architecture, urbanism and cultural heritage", registered in the National Research Council - CNPq (Brazil), gathering researchers from the Federal University of Pará and the Oswaldo Cruz Foundation (FIOCRUZ) and aims to continue the International Colloquium Luso-Brazilian of Assistance Architecture from the Modern Age to the contemporaneity: spaces, functions and actors, held in November 2015 in Lisbon, integrating in this session the Federal University of Alagoas. As part of the research conducted by this group, research on health architecture were extended, gaining new contours with the inter-institutional dialogue in Brazil and Overseas, covering the health care of the population of general and their specificities as the institutionalization of assistance to workers' health, always based on the materiality oh Architecture, in which aesthetic and technical aspects are added to the sociocultural demands.
\end{abstract}

Keywords: assistance architecture, health heritage, hospital models.

\section{Resumo}

Inscrita no corpo das investigações sobre a arquitetura da saúde, a definição de concepções da Arquitetura, cumprindo o papel de 'auxílio' proposto sob o signo da caridade, da filantropia e da assistência, constitui o cerne deste artigo. Propõe-se destacar o projeto de arquitetura, considerando o entrelaçamento desses dois campos de saber: arquitetura e saúde, na trajetória histórica da instituição hospitalar, seja em aspectos físico-funcionais, estéticos, médico-científicos, tecnológicos, geográficos, socioculturais, políticos ou econômicos. Cumpre ainda compreender a Arquitetura assistencial no contexto de seus financiadores e projetistas, sejam eles monarcas, arquitetos, médicos, mecenas, filantropos ou instituições, acentuando os trânsitos entre Brasil e Portugal, nos 
séculos XIX e XX e o diálogo com pesquisadores de outros domínios territoriais. Este artigo, que apresenta os resultados da sessão que compôs o IV ENANPARQ, faz parte do Grupo de pesquisa "Saúde e Cidade: arquitetura, urbanismo e patrimônio cultural", registrado no Conselho Nacional de Pesquisa - CNPq (Brasil), reunindo pesquisadores da Universidade Federal do Pará e da Fundação Oswaldo Cruz (FIOCRUZ) e busca dar continuidade ao Colóquio Internacional Arquitetura assistencial luso-brasileira da Idade Moderna à contemporaneidade: espaços, funções e protagonistas, realizado em novembro de 2015 em Lisboa, em cooperação entre a Universidade Federal do Pará, a Universidade de Lisboa e a Universidade Lusíada, integrando neste painel a Universidade Federal de Alagoas. No âmbito das pesquisas realizadas por esse Grupo, as investigações sobre a arquitetura da saúde ampliaram-se, ganhando novos contornos com o diálogo interinstitucional, no Brasil e Além-Mar, abrangendo a assistência à saúde da população de um modo geral e suas especificidades como a institucionalização da assistência à saúde do trabalhador, sempre entendidas a partir da materialidade da Arquitetura, em que aspectos estéticos e técnicos somam-se às demandas socioculturais.

Palavras-chave: arquitetura assistencial, patrimônio da saúde, modelos hospitalares, intercâmbios culturais.

\section{Resumen}

Inscrita en el cuerpo de investigación sobre la arquitectura de la salud, la definición de los conceptos de la arquitectura, el cumplimiento de la función de "ayuda" propuesto bajo el signo de la caridad, la filantropía y servicio, está en el corazón de este artículo. Se propone destacar el diseño arquitectónico, teniendo en cuenta la interrelación de estos dos campos del conocimiento: la arquitectura y la salud, la trayectoria histórica del hospital, ya sea en aspectos físicos y funcionales, estéticas, médicas y científicas, tecnológicas, geográficas, socio-culturales, políticos o económica. También hay que entender la arquitectura de atención en el contexto de sus patrocinadores y diseñadores, ya sean monarcas, arquitectos, médicos, clientes, filántropos e instituciones, acentuando los tránsitos entre Brasil y Portugal en el siglo XIX y XX y el diálogo con investigadores de otros ámbitos territoriales . Este artículo, presenta los resultados de la sesión que componían el IV ENANPARQ, forma parte del Grupo de Investigación "Salud de la Ciudad: la arquitectura, el urbanismo y el patrimonio cultural", registrada en el Consejo Superior de Investigaciones Científicas - CNPq (Brasil), la integración de investigadores de la Universidad Federal de Pará y la Fundación Oswaldo Cruz (Fiocruz) y de búsqueda para continuar la arquitectura Coloquio Internacional luso-brasileña de la salud de la edad moderna a la contemporánea: espacios, funciones y actores, que se celebró en noviembre de 2015, en Lisboa, en colaboración con la Universidad Federal de Pará, la Universidad de Lisboa y el Lusíada Universidad, la integración de esta Panel de la Universidad Federal de Alagoas. Como parte de la investigación llevada a cabo por este grupo, la investigación sobre la arquitectura de la salud se ampliaron, ganando nuevos contornos con el diálogo inter-institucional en Brasil y en el extranjero, que cubre el cuidado de la salud de la población de general y sus especificidades como la institucionalización de la asistencia a la salud de los trabajadores, siempre entendido a partir de la materialidad de la arquitectura, en la que se agregan los aspectos estéticos y técnicos a las demandas socioculturales.

Palabras-clave: arquitectura de la salud, la herencia de la salud, modelos de hospitales, los intercambios culturales. 


\section{Narrating the origins}

$\mathbf{W}$ e will present the beginning of our participation in health studies, bringing together paths that start from academic projects based at the University of Alagoas, as well as through Rede Brasil: Patrimônio da saúde (Brazil Network: Heritage of health), coordinated by FIOCRUZ, involving the authors of this text in personal and scientific plans.

The investigations on Assistance Architecture at the Federal University of Alagoas followed the journey of Marcia Monteiro started in 1989 with the extension project UFAL's Architecture Office at the Severiano da Fonseca General Hospital (former Sanatorium), in Maceió, created by professor Lucia Leimback, to which the architect Sandra Cavalcanti and the professor Patricia Melro joined. This hospital with pavilion typology, located in the upper part of the city, in the neighborhood of Farol, was inaugurated in 1947, integrating the healthcare infrastructure of the National Campaign of the League against Tuberculosis in Brazil. With the advent of antibiotics and ambulatory therapeutics and the reduction of admissions, it lost its original isolation function, becoming a medium-sized general hospital. In the 80 of the twentieth century, it had 200 beds, made possible by the new medical services.

At the beginning of the office in 1989, the institution, known as Sanatorium, which gave its name to the neighborhood, operated precariously. Many patients, abandoned by the family, remained as hospital residents, reinforcing the stigma of isolation and social exclusion, mirroring the poverty and neglect of the most vulnerable population. The project aimed to modernize and humanize their spaces to print a new image and attract patients. With the retirement of Professor Lúcia Leimbeck, Márcia Monteiro took over the coordination of the office, wherein the learning opportunity in the hospital area attracted students from UFAL and the Federal Technical School (ETFAL). Therefore, Monteiro specialized in Hospital Administration by the São Camilo University (SP), initiate studies on hospitals in Maceió, and attend congresses in São Paulo, where she met the architect Jarbas Karman, authority in the matter.

In 1992, she was invited to make projects for the Foundation of the Sugar and Alcohol Agroindustry of Alagoas, known as the "Hospital do Açúcar" (Sugar Hospital) of Alagoas, also located in the neighborhood of Farol, an experiment that lasted until 1997. The building was inaugurated in 1957, with the project 
of the architect Manoel Messias de Gusmão, and was built by mill owners, sugar cane suppliers and planters allied to the Instituto do Açúcar e do Álcool" (IAA) (Sugar and Alcohol Institute) in order to assist the health of workers in the sugarcane economy. This hospital had 550 beds in wings for individuals and covenants, among them those of the Foundation-Hospital, with differentiated assistance by category of worker, and wings for Sistema Único de Saúde (SUS) (Unified Health System) care, coming from the quotas of the IAA transferred to the Ministry of Health, after its extinction, in 1990.

From these experiences at the Sugar Hospital and former Sanatorium, the architect extended the research focus, which revealed health care intertwined with labor relations for the system and the context of public health in the country. She furthered her studies with doctoral research on hospitals, emphasizing the North American model of the Districtal Hospital, which inspired the Alagoas hospital project, resulting in the thesis "Saúde \& Açúcar: História, economia e arquitetura do Hospital do Açúcar de Alagoas, 1950-2000" (Health \& Sugar: History, Economy and Architecture of the Alagoas Sugar Hospital, 1950 - 2000), guided by the historian José Jobson de Andrade Arruda, in the post-graduation in Economic History of FFLECH-USP between 1997 and 2001.

Later, Márcia Monteiro was invited by the Historical and Geographical Institute of Alagoas (IHGAL) to write a book on the history of health in the State, whose research focused on the Imperial period, having as sources documents of Presidents of the Province, Collections of laws and newspapers, besides the work Oswaldo Cruz Monumenta Histórica, which is about the 100 years of public health services in Brazil, starting from the arrival of the Royal Family. This research resulted in the book "A saúde em Alagoas no Brasil Império: caminhos e descaminhos" (Health in Alagoas in Brazil Empire: Paths and Misplaces), published by IHGAL in 2004, with the participation of Professor Fernando Antonio Gomes de Andrade (UFAL) and reedited by Edufal, in 2013, under the title "A saúde pública em Alagoas no Brasil Império: caminhos e descaminhos" (Public health in Alagoas in Brazil Empire: Paths and Misplaces).

Between 2007 and 2010, in technical cooperation at the Federal University of São Paulo (UNIFESP), she taught disciplines at the Department of Preventive Medicine, where she studied about the SUS and the elderly population, for which she elaborated housing 
and villages projects, besides the headquarters of the Center for Aging Studies and the Open University of the Third Age, associating assistance, coexistence, research and extension.

Other publications join the trajectory: the article "Homens da cana e hospitais do açúcar: uma arquitetura da saúde no Estado Novo" (Men from sugarcane and sugar hospitals: an architecture of health in the New State) published in Manguinhos Magazine (2011) and the book "Hospital do Açúcar de Alagoas: arquitetura e assistência à saúde: 50 anos de história" (Alagoas Sugar Hospital: architecture and health care: 50 years of history), published by Edufal (2015), contextualizing the conditions of life and health of the population, in the 1950s and the Alagoas Sugar Hospital from its conception until the 2000s.

The first moment in which Cybelle Miranda joined the research on Assistance Architecture occurred when, in 2009, she was invited with Professor Jane Felipe Beltrão to integrate the team of Belém in the Brazil Network: National Inventory of Cultural Heritage of Health: buildings and collections, which is part of the priority actions defined in the scope of the Latin American Network of History and Cultural Heritage of Health, created in 2005, an initiative coordinated by the Ministries of Health of Brazil and Chile, House of Oswaldo Cruz (Fiocruz) and BIREME -OPAS, from which she participated with the Patrimony of / in Health project in Belém-Pará. The general coordination of Brazil Network was in charge of the Architect Renato da Gama -Rosa Costa and the Historian Gisele Sanglard.

This first initiative allowed the elaboration of 23 sheets referring to buildings aimed at health in the city of Belém, Pará, among which were studied active institutions as well as missing examples on the landscape. Thus, the dialectical perspective between memory and forgetfulness has become essential to characterize the valuation of health architecture as patrimony.

Continuing this first activity, Miranda obtained support from CNPq for the project "Memória e Cidade: Itinerários da Saúde na Belém Colonial e Imperial" (Memory and City: Health Itineraries in Colonial and Imperial Belém), developed between 2011 and 2013. The project counted with the partnership among members of the Postgraduate Program in Architecture and Urbanism (PPGAU) in conjunction with Professor Jane Felipe Beltrão of the Postgraduate Program in Anthropology and Archeology (PPGA) and Professor Marcio Couto Henrique of the Postgraduate Program in Social 
History of the Amazon (PPGHIS), all of them situated in UFPA, being located in the Laboratory of Memory and Cultural Heritage (LAMEMO/FAU). Featuring the research network is Professor Fernando Jorge Artur Grilo and the researcher Joana Maria Balsa Carvalho de Pinho, at the Institute of Art History of the University of Lisbon, besides of the Master Architect and Urbanist, active in the city of Porto, Silvana Cássia Miranda Ferreira.

In 2013, the study of the architecture of the health buildings in Belém was continued with the project "Classicismo nos Hospitais da Misericórdia e da Beneficência na $2^{a}$ metade do século XIX: trânsito entre Brasil e Portugal" (Classicism in the Hospitals of Mercy and Beneficence in the second half of the nineteenth century: transit between Brazil and Portugal), still in progress. As a result of the analyzes carried out in the previous research, the predominance of imperial classicism as a style used in hospitals was a factor that was feed by the relationship with Portugal. Thus, a new way of investigation opens, that can unravel the relations between the Portuguese institutions and those implanted in the imperial Belém. Also in 2013, Miranda joined the Lusophone and European Center of Literature and Cultures of the University of Lisbon (CLEPUL), when the Research Office "Misericórdias e Instituições similares: assistência, património e cultura" (Mercies and similar institutions: assistance, heritage and culture) was created.

The International Colloquium Luso-Brazilian "Assistance architecture: from the Modern Age to the contemporary: spaces, functions and protagonists" occurred on November 9 and 10, 2015, was organized by partner institutions in the investigation of the Heritage of health, gathering communications that contemplate the understanding of the Assistance architecture, in the context of the Luso-Brazilian space, providing a global and multidisciplinary approach with the characterization of the various architectural typologies associated.

The organization of this event was made up by researchers linked to the ARTIS -Institute of Art History of the Faculty of Letters) of the University of Lisbon and to the Research Office Mercies and similar institutions: assistance, heritage and culture (CLEPUL), both from the University of Lisbon, the CITAD Research Center of the Lusíada University and the research group "Health and City: Architecture, Urbanism and Cultural Heritage", registered at CNPq (Brazil), integrating researchers from the Federal University of Pará (UFPA) and 
the Foundation Oswaldo Cruz (FIOCRUZ). This event aimed to disseminate to society the results from which it is possible to intervene effectively in the preservation and rehabilitation of the heritage assets of the Mercies and other philanthropic entities, which concern to health protection in Portuguese-speaking countries.

Twenty-four papers were selected, covering subjects that include institutions such as the Mercies, Sanatoriums, Psychiatric Hospitals, and other specialties in Portugal and Brazil.

\section{Focusing on themes developed in the field of architecture and urbanism in the nineteenth and twentieth centuries}

\section{Health Heritage}

Renato da Gama-Rosa Costa, researcher at the House of Oswaldo Cruz, addresses the issue of the modern health heritage and the challenges for its valorization, emphasizing the example of Rio de Janeiro (2009). It reports on the, still recent, trajectory of the appreciation of the architectural collection of health, especially the modern one, which has gained prominence since 2004 at the Meeting of DOCOMOMO held in France, during the first day dedicated to the history and rehabilitation of built sanatoriums between the Great World Wars. It highlights the movement in Latin America, led by the actions of Brazil Network, and the difficulties in including the buildings built between the 30 s and 50 s of the 20th century in the classified goods lists, due to the no attribution of these as part of modern architecture (COSTA, 2009).

The author concludes that, from the first inventory carried out in the Midwest, South and Southeast capitals, modern projects are concentrated in the name of a few architects such as Jarbas Karman, in Goiânia; Rino Levi and Oswaldo Bratke in São Paulo, Paulo Motta in Florianópolis and Raffaello Berti in Belo Horizonte, as well as Jorge Moreira Machado in the Clinic's Hospital in Porto Alegre and Oscar Niemeyer in the Hospital Prof. Edmundo Vasconcellos in São Paulo.

According to Renato Costa, the production of the 30s and $40 \mathrm{~s}$ in Rio de Janeiro is marked by projects developed by the teams of the Federal District City Hall, the Institutes for Retirement and Pension (IAPs), the Special Public Health Service (SESP), the Work Division of the Ministry of Health and the National Campaign against Tuberculosis (CNCT). 
From the 50s, the author notes an aesthetic maturity in conceptions, with a clear reference to Le Corbusier, with an apparent structure, a free plant, the idea of a prototype, generating the possibility of industrial reproduction. Examples include the Curicica Sanatorium of Sergio Bernardes, the Lagoa Hospital of Niemeyer and Helio Uchoa, and the University Hospital of the University of Brazil of Jorge Machado Moreira.

This is due to the protagonism of the architects in the conceptions of design, previously outlined mainly by medicine doctors, having as a landmark the Course of Hospital Planning promoted by the Institute of Architects of Brazil, section of São Paulo, in 1953. The parties oscillated between the Model pavilion in the Sanatorium and the vertical monoblock in the other examples, using architectonic and constructive solutions pertinent to the context of the time.

During the I ENANPARQ (2010), eight communications were presented at the Thematic Symposium "Architecture and Health, History and Heritage, Network Experiences", coordinated by Renato da Gama-Rosa Costa. Highlighting hospitals in the Northeastern region, we have the texts "The Influence of Districtal Hospital (EUA) at Sugar Hospitais in Brazil" by Márcia Monteiro, in which the author addresses the Sugar Hospitals in Pernambuco and Alagoas; "The hospital building as an instrument for healing", proposed by Luiz Amorim, Laura Alecrim and Carolina Brasileiro, from the analysis of sanatoriums and leprosariums in Pernambuco relates the medical prescriptions with the organization of space, showing how architecture can be an instrument of cure and the text of Maria Renilda Barreto and Christiane Souza, "Cultural Heritage of Health in Bahia: 150 Years of History", which presents the study of health institutions based in Salvador founded between 1808 and 1958, through the analysis of the architectural, historical and iconographic collection of the institutions.

The article "Raffaello Berti's contribution to the cultural heritage of health in Belo Horizonte" by Rita Marques, Anny Silveira and Claudia Martins, reports the research on the Cultural Heritage of Health in Belo Horizonte, between 1897 and 1958, in which the name of Raffaello Berti came to light, an Italian architect settled in Brazil, who spread the monoblock vertical model in the hospital buildings of the region.

In the article "Memory of Health Care in Belém-PA: Architecture as a Document", Cybelle Miranda shows that, at first, health in Belém was carried out by ins- 
titutions of portuguese origin, such as Mercy's Holy House, Third Order of São Francisco of Penitence Hospital and Portuguese Beneficent Hospital. The volumetric structure of these institutions represents a landmark in the urban landscape of the city, as well as the internal structure itself is a component of the memory of the Pará's people (MIRANDA, 2010). Preserving the theme, the article "Memories of concrete: health architecture in Santa Catarina" by Ana Amora shows the role of health buildings as a support of memory, as well as the role of these buildings in the construction of the city of Florianopolis.

The article "Juliano Moreira Colony: Uses, permanencies and landscape" of Tainá Reis shows the transformations that occurred in the Juliano Moreira Colony due to the uses and permanencies in its three phases: colonial farm, institution of psychiatric treatment and scientific institution, allowing a counterpoint between the therapeutic practices and the typology of isolation colony influencing the landscape of Rio de Janeiro.

Renato Gama-Rosa proposes a comparative perspective of the modern context in "Clinics Hospitals of Salvador, São Paulo, Porto Alegre and Rio de Janeiro: architecture for health between two modernities", relating the spatial and aesthetic conceptions in force between the 30 s and 40 s of the twentieth century and the innovative proposals brought by Le Corbusier.

In 2013, the dossier Heritage in Health was published in the Amazônica Journal of the Postgraduate Program in Anthropology and Archeology of UFPA:

\begin{abstract}
The idea of producing a dossier came from the participation in the Brazil Network project: National Inventory of Cultural Heritage of Health: built goods and collections, (...) The proposal brings with it the perspective of knowing and communicating the possibilities of this patrimony, existing in each country, indicating the trails of the History of Health and Disease, from the identification and inventory of buildings and collections, in an attempt to preserve them since they integrate, as a right, the memory of all citizens (BELTRÃO, MIRANDA, HENRIQUE , 2013, p: 1).
\end{abstract}

The Dossier brought together ten original articles, covering themes that cross the knowledge of Architecture, Anthropology, Museology and History, to which Brazilian and Portuguese authors contributed, in which historical narratives blend into contemporary themes, as exemplified in the texts "The slaves of Mercy" by Marcio Couto Henrique and "Art, Clinic, Science and Heritage: a Collection of Moldings of a former Hospital of Dermatology and Syphilis of Lisbon", elaborated by Cristina Bastos, Ana Delicado and Antonio Matos. 
In III ENANPARQ (2014), the Symposium "Memory and Preservation of the Cultural Patrimony of Health: the luso-brazilian context" brought together researchers who treat objects that bring relations between Brazil and Portugal. In the studies on health architecture in Belém, Miranda (2014), in her article "Health itineraries in colonial and imperial Belém", addresses the displacements of welfare institutions in the city between the eighteenth and nineteenth centuries, emphasizing the architectural features as signs that Denote changes in the urban landscape of Belém, as the author says:

From the intersection with the current physiognomy of the sites and hospital buildings, it is possible to reveal the losses / deletions so that, in the proposed itineraries, the city dweller and the visitor can refer to the material vestiges of the urban change trajectory (MIRANDA, 2014, p: 2).

The article "Domingos Freire Isolation Hospital" by José Abreu Júnior and Aristóteles Miranda reconstructs the trajectory of the Domingos Freire isolation hospital in Belém, whose primary function was the treatment of patients with yellow fever and later the treatment of tuberculosis. Built during the hygienist period at the turn of the nineteenth century to the twentieth century represents the health architecture of the Amazon's Belle Époque. Becoming inadequate to meet the new medical requirements, it was deactivated and demolished in 1960, giving space to the João de Barros Barreto Hospital.

Renato Gama-Rosa Costa deals with the "Hospital-Sanatorium of the Portuguese Colony of Brazil in Coimbra. Relations between Portugal and Brazil in the area of health and cultural heritage". Built in Coimbra with the support of the Portuguese Beneficence of Rio de Janeiro, this hospital was inaugurated in 1935 and is in operation until today, but faces a constant threat of closure due to discussions of new health policies in Portugal.

The article "Fafe - a Portuguese city built by the 'brazilians of torna-viagem"' in the transition from the nineteenth to the twentieth century by Daniel Bastos shows the role of the emigrate portuguese persons that returned to their birth place in the construction of the Portuguese city of Fafe, located in the district of Braga, Portugal. The transformations that occurred in this city are due to the eighteenth-century emigration that provided the construction of palatial homes and public buildings, such as the Hospital of São José. It was inaugurated in 1863, administered by Fafe' s Holy House of Mercy, being built in the architectural molds 
of Portuguese Beneficence Hospital of Rio de Janeiro, in Brazil.

In the studies on health in Alagoas, the researchers Monteiro and Andrade $(2009 ; 2013)$ in their book "Public health in Alagoas in Brazil Empire: Paths and Misplaces", established a panorama of living conditions and public health in Alagoas by material conditions, medical-scientific knowledge, the initiatives of the authorities in relation to health care and compliance with legislation and actions taken by the Emperor to protect the population.

In 2015, the Architect Cibelly Figueiredo presented the dissertation "D. Luiz I Hospital of the Meritorious Beneficent Portuguese Society of Pará as document / monument". This research presented the headquarters building of D. Luiz I Hospital, built in 1877 as a cultural, material and immaterial good and as a support for the memory and identity of the Portuguese immigrants who came to Belém, Pará. Approach and data collection that provided the recognition of the headquarters building as historical, architectural and cultural heritage of the history of health in the North of Brazil (FIGUEIREDO, 2015).

Thus, with the conclusion of the Inventory of Health Heritage, there was continuity in the research on this patrimony in its architectural aspect, of which we highlight the publications resulting from the research developed in the research group "Health and City: architecture, urbanism and cultural heritage" carried out by researchers from the Federal University of Pará, in a network between the disciplines Architecture, Anthropology and History. The further development of the research on the patrimony of health in the capital of the state of Pará made possible the aesthetic and symbolic characterization of these buildings, in addition to their functional importance. The discussion between memory and forgetfulness is present in texts that deal with physical degradation and loss of the aesthetic characteristics, providing research on constructive and decorative techniques that may favor the restoration of the period characteristics of these buildings.

\section{Humanization in health spaces: user perception and design method}

The discussion about hospitals and the humanization of care architecture is complex and needs contextualization, observing the historical process of illness and assistance of the populations. At present, the expectations of a good health service are directed to the 
technical quality and interaction between the teams of professionals in the health, social and logistic support areas, the skills in the respective areas and the technological potential of the hospital institution. Despite the diversity of material and human resources, the process of hospitalization historically and today removes from the individual, as a patient, their protagonism in the treatment process, the conviviality with family members, autonomy and often their own identity, issues that mobilize researchers and professionals in the search for effective changes in procedures and spatialities.

In the article "The hospital and the historical process of hospitalization", Monteiro and Neder Filha (2003) observe that at any time the gesture of caring is accompanied by distinct, often ambiguous feelings of those who rescue or are rescued and witness the rescue, causing impressions about times and places, especially at the hospital where care is provided. The hospitals own history, full of symbolism, whether through stigma or experiences, interferes in the imaginary and hospitalization process from its earliest days. The authors mention the institutions organization for the protection and treatment of slaves, fighters and soldiers, categories considered useful to society in Classical Antiquity; the institution of assistance of religious character and later the laic one in the Middle Ages, the paradigm shift with the hospital with a therapeutic function, humanistic and scientific view, in the Modern Era, becoming a technological paraphernalia complex in the Contemporary Age. Just as today, each solution aimed at the possible reception giving form to the assistance according to the visions of world and the limit of the medical-scientific knowledge (MONTEIRO, NEDER FILHA, 2003).

The papers presented in the session "Assistance architecture and health: discussing conceptions and protagonists" offer an overview of this process of hospitalization between the nineteenth and twentieth centuries, in which the assistance architecture of each case mirrors the conceptions of health and humanistic, holistic and the pragmatism of the project operations at the service of the users well-being and the socio-environmental conditions.

Antonio Pedro Alves de Carvalho in the text "Meio ambiente e estabelecimentos assistenciais de saúde: da segregação à humanização" (Environment and health care establishments: from segregation to humanization) makes a brief history of care architecture, based on the Hippocratic rational assumptions, in 
the Classical Era. It highlights the medieval hospitals, built next to monasteries in the form of a church nave, where the health cares were acts of faith and christian resignation, isolation and preparation for death, and the paradigm shift which occurred in the Modern Era with the pavilion hospitals, consolidated the functionalist and hygienist conception of healing by controlling the environment, mirroring new relationships and organization of services and professionals.

This conception, which at the time introduced restrictions of patients by ward, separation by illness, spacing between beds, air gap, distance between blocks and hospital with the city, appropriating natural resources (light, ventilation, gardens) such as architecture resources as part of hygiene care and well-being for health recovery, was taken up by the author on another scale as necessary for the humanization of health care in modern times.

Carvalho (2016) advocates the possibility of minimizing negative effects on the environment and public health, as opposed to the hospital-centered model characterized by vertical monoblock, which results in physically and financially unhealthy, unsanitary, unsustainable health complexes with negative effects on the environment and the needs of its users. In his analysis he prescribes the return to small and medium-sized solutions, aiming at the proximity between people and the use of natural resources, integration of spaces with nature and healthier practices.

Ana Paula Vieceli, in "A casa e o cais: disjunção da arquitetura no encontro com os lugares da loucura" (The house and the port: disjunction of architecture in the encounter with the places of madness) analyzes the spatiality of a Psychosocial Attention Center built after the Psychiatric Reform in view of its relation with the space concept of the anti-asylum movement, aiming through qualitative analyzes, to identify new concepts and practices distinct from the exclusionary models that preceded it. The Casa-CAIS, as it is known, results from a residence adaptation built in 1951 in Porto Alegre.

According to the author, the house provides, in part, the requirements for the spaces of madness adopted after the anti-asylum reform, observing aspects of segregation in the layout of indoor environments and internal flows, the lack of more spaces of reception and accessibility, also obligatory and not yet served. For Vieceli (2016), the technical team interacts little 
with the users, making it more like an observer, so the impression is of the House as a place of learning and shelter rather than reception.

She observed in the dynamics of the team a reflection of the hardness or containment of the spatiality demonstrating that there is much to do for the humanization of care and assistance architecture and that despite the revolution or rupture of the way of conceiving the madness and its spaces, we are still in transition stage.

The text "O pioneirismo e a obra de Frei Eugênio Maria de Gênova em Uberaba e a construção de uma cidade mais salubre" (The pioneering and the work of Frei Eugênio Maria de Genoa in Uberaba and the construction of a healthier city) by Andreia de Freitas Lopes and Marília Teixeira Vale presents the hygienic interventions of Frei Eugênio and his works in Uberaba (MG), in the context of healthy conditions and urban planning of cities in the nineteenth century, reverberating the decisions of the Court in Brazil, with its modernizing and civilizing project. This protagonist, linked to the Capuchin Order, played an important role as a collator for souls, buildings and territories, also acting in the urban areas, with a pioneering spirit backed by his training as an engineer.

The questions addressed by Lopes and Vale (2016) regarding the influence of medical theories on architectural treaties and hygienist and police measures for disease and patient's restraint, and the control of population and cities in the nineteenth century indicate in a certain way the search for humanization of relations, of public and private buildings, although by cleaning and discipline. Actions such as the isolation of patients and the distance from urban centers to areas such as cemeteries, slaughterhouses, lazaretos and hospitals are attempts to oppose material deprivation and chaos.

Leila Lopes and Natalia Naoumova in "O uso da cor como ferramenta de humanização de ambientes de assistência à saúde infantil sob a percepção do usuário: caso de estudo Pelotas, RS" (The use of color as a humanization tool for child health care environments under the perception of the user: case study Pelotas, RS) present qualitative analysis related to the use of color and its impact in child health care environments, aiming at color planning in similar environments.

The question dealt with by Lopes and Naoumova (2016) is detailed in the holistic view and concepts 
of an integrative assistance, mainly by the incorporation of psychological and sensorial aspects to the contemporary conceptions of health, which reverberated in the studies of the professionals, throughout the $X X$ and XXI centuries. The public target is the child, for whom is planned an architecture with new spatial conceptions, in order to prevent stress and others bad sensations.

The article "Do hospital de Pronto Socorro do Recife ao hospital da Restauração: o espaço hospitalar em dois tempos" (From the Recife's Emergency Hospital to the Hospital of Restoration: the hospital space in two times) proposed by Luiz Amorim and Cecília Ribeiro describes the architectural conceptions of two examples of the hospital architecture from Pernambuco: the Emergency Hospital of Recife and the Hospital of Restoration. Both buildings were planned in the mid-twentieth century, adopting modernist references that mirror the functionalist logic, such as hierarchical principles of sectors and flows, where the emphasis is the hospitalization anchored by ambulatory, diagnostic and surgical services.

Amorim and Ribeiro (2016) detail the two spatial arrangements looking for differences that reveal significant changes in the principles of hospital planning, considering the demand for projects oriented by the search for efficiency and improvement of the hospital architecture that occurred in Brazil in the 1950s and 1960s. In this decade, it was established the organization of a project practice from courses held in São Paulo and the United States of America. The authors also analyze the relationships of professional teams in this process of project design.

In the same line of protagonism and temporality, Franciely Daiane Massarenti de Almeida discusses the modernist projective activity of the architect in the text "Rino Levi e a arquitetura da saúde: simbiose entre arte e técnica" (Rino Levi and the architecture of health: symbiosis between art and technique), emphasizing the formation in Italy as an integral architect and his performance as office operations coordinator. In addition, the modus operandi in the design of the projects, in which the program interacts with the form and the architect seeks the integration with the exterior and the environmental comfort with the use of the natural resources. In his case studies, Almeida (2016) presents a vertical hospital and a pavilion one, emphasizing in the first case the functionalist logic and the hierarchical and ordering principles following the same reasoning presented by Amorim and Ribeiro 
(2016) and the second, the holistic bias of spatial conceptions with pavilion typology that allows the closest relationship with nature and among people so valued in Carvalho' s analyzes (2016) and also addressed by Vieceli (2016) and Lopes and Naoumova (2016).

\title{
Final Thoughts
}

Sanglard (2006) calls attention to the role of philanthropy in the hospital assistance process in Brazil. The author emphasizes that, with the emergence of non -religious brotherhoods in the late Middle Ages, these

\begin{abstract}
have become, to some extent, 'mediators' and depositaries of the Catholic philanthropy, situated between the philanthropist and the charity. On the latter, there was also a change that would characterize and give it a mutualist character, since hospitals are no longer open to all, but only to members of a certain brotherhood or confraternity (SANGLARD, 2006, p. 13).
\end{abstract}

Sandra Cavallo, quoted by the author, when analyzing the Turim Hospitals from the sixteenth century onwards, emphasizes that the dominant characteristic of charity in the monarchical regime is aid and privilege, expressed in rational calculations in which prestige, influence and competition among the different social groups motivated the actions of support to the places of reception of the patients.

Throughout the eighteenth century began the process of medicalization of these spaces, whose purpose was to make them machines to heal. In French society the idea of knowledge progress, which should be extended to the other layers of society, generated a change of habits that would allow a more orderly and sanitized city. In the nineteenth century renewed forms of beneficence appeared which the author calls 'sophisticated forms of charity'. Like this,

The 'modernization' of charity was accompanied by social tension and political discussions, in which charitable and / or philanthropic actions are side by side with those that have been implemented, even if timidly, by the State (SANGLARD, 2006, p. 19).

The prolonged link between the Faculties of Medicine and the Mercies in many Brazilian capitals, such as the case of Rio de Janeiro, Porto Alegre, Salvador and Belém, delayed the process of effective control of the hospitals by doctors, which only happened effectively in the 20s in the capital of the country, and was consolidated in the second half of the twentieth century in many other cities. 
The careful look for the past allows us to make the framing of architecture as a project and material culture, object of several looks and experiences, in which the performance of the designer has only recently been consolidated, given the various social actors involved and the meanings built historically for the terms charity, philanthropy and assistance.

Paying attention to the need to reflect about the hospital as a receptacle of memory and the history of the city, medicine, care and even Architecture, as an object that teaches us about the ways of thinking and living of past generations. Thinking of the hospital project in line with the medical culture but also with the local culture, adding traditional knowledge and differentiated expectations, when we think of a culturally diverse country in which the climate, materials, geographical and landscape morphologies cry out for non-uniformity solutions.

We highlight the experience of the american Architect Charles Jenks in the book Architecture of Hope, which addresses innovative Day-houses solutions to cancer treatment in the UK, which originated from the initiative of his wife Maggie, then diagnosed with the disease.

Gathering a complexity of forms, the program for Maggie's cancer caring Center aims at architecture as the constructor of the metaphor of hope, a projection for the future. With a realistic utopian sense, the program thinks the patient with an incurable disease not as a terminal patient, but as a human being who aspires to live better (MIRANDA, 2016. s. p.).

Thus, this article brings together part of the trajectory of health care architecture studies in Brazil, a poignant and recurrent theme in the daily life of the population, and which still demands studies on the appropriate design methods for the various social, economic and cultural situations. From the texts that compose the thematic session we coordinate, we can see the guiding line of humanization, which points out the way of the past to think about the present, in which the revision of modern concepts of Architecture to adapt to the needs of endowing the spaces of sensory attributes such as hospitality, security, tranquility and harmony. 


\section{References}

ALMEIDA, Franciely Daiane Massarenti de. Rino Levi e a arquitetura da saúde: simbiose entre arte e técnica. Anais do IV ENANPARQ, Estado da Arte. Porto Alegre, 25-29 julho 2016 [recurso eletrônico] / Organização: Claudia Costa Cabral, Carlos Eduardo Comas. Porto Alegre: PROPAR/UFRGS, 2016. [ISSN 2358-6214]

AMORIM, Luiz; RIBEIRO, Cecilia. Do hospital de pronto socorro do Recife ao hospital da restauração: o espaço hospitalar em dois tempos. Anais do IV ENANPARQ, Estado da Arte. Porto Alegre, 25-29 julho 2016 [recurso eletrônico] / Organização: Claudia Costa Cabral, Carlos Eduardo Comas. Porto Alegre: PROPAR/UFRGS, 2016. [ISSN 2358-6214]

ALVIM, Angélica; SANTOS JUNIOR, Wilson (orgs). Anais do III ENANPARQ Arquitetura, Cidade e Projeto: uma construção coletiva. São Paulo: Universidade presbiteriana Mackenzie; Campinas: Pontifícia Universidade Católica de Campinas, 2014. [CD-ROM].

BELTRÃO, Jane Felipe; MIRANDA, Cybelle Salvador; HENRIQUE, Márcio. Patrimônio em Saúde - Dossiê. Amazônica: Revista de Antropologia (Online).251-252, v.2, 2013.

CARVALHO, Antonio Pedro Alves de. Meio ambiente e estabelecimentos assistenciais de saúde: da segregação à humanização. Anais do IV ENANPARQ, Estado da Arte. Porto Alegre, 25-29 julho 2016 [recurso eletrônico] / Organização: Claudia Costa Cabral, Carlos Eduardo Comas. Porto Alegre: PROPAR/UFRGS, 2016. [ISSN 2358-6214]

COSTA, Renato da Gama-Rosa. Patrimônio moderno da saúde e os desafios para a sua valorização. O exemplo do Rio de Janeiro. VIII Seminário Docomomo Brasil. Rio de Janeiro, 2009. http://www.docomomo.org.br/seminario\%208\%20pdfs/160.pdf. Acesso em: 14 jul 2014. COSTA, Renato da Gama-Rosa. Hospitais de clínicas de São Paulo, Salvador, Porto Alegre e Rio de Janeiro: arquitetura para a saúde entre duas modernidades. I Encontro Nacional de Pós-Graduação e Pesquisa em Arquitetura e Urbanismo. Anais...Rio de Janeiro: PROURB, 2010. http://www.anparq.org.br/dvd-enanparq/simposios/15/15-13-2-SP.pdf. Acesso em: 10 mar. 2016.

FIGUEIREDO, Cibelly Alessandra Rodrigues. Hospital D. Luiz I da Benemérita Sociedade Portuguesa Beneficente do Pará como documento/monumento. Dissertação (Mestrado em Arquitetura e Urbanismo). Programa de Pós-graduação em Arquitetura e Urbanismo, Universidade Federal do Pará. Belém, 2015.

LOPES, Andreia de Freitas; VALE, Marília Maria Brasileiro Teixeira. O pioneirismo e a obra de frei Eugênio Maria de Gênova em Uberaba e a construção de uma cidade mais salubre. Anais do IV ENANPARQ, Estado da Arte. Porto Alegre, 25-29 julho 2016 [recurso eletrônico] / Organização: Claudia Costa Cabral, Carlos Eduardo Comas. Porto Alegre: PROPAR/UFRGS, 2016. [ISSN 2358-6214]

LOPES, Leila; NAOUMOVA, Natalia. O uso da cor como ferramenta de humanização de ambientes de assistência à saúde infantil sob a percepção do usuário: caso de estudo Pelotas, RS. Anais do IV ENANPARQ, Estado da Arte. Porto Alegre, 25-29 julho 2016 [recurso eletrônico] / Organização: Claudia Costa Cabral, Carlos Eduardo Comas. Porto Alegre: PROPAR/ UFRGS, 2016. [ISSN 2358-6214]

MACHADO, Denise P. et al. (org.). I Encontro Nacional de Pós-Graduação e Pesquisa em Arquitetura e Urbanismo. Anais... Rio de Janeiro: PROURB, 2010. [CD-ROM].

MIRANDA, Cybelle Salvador; BELTRÃO, Jane Felipe; HENRIQUE, Márcio Couto; BESSA, Brena Tavares. Santa Casa de Misericórdia e as políticas higienistas em Belém do Pará no final do século XIX. História, Ciências, Saúde-Manguinhos (Impresso), v.22, p.525 - 539, abrjun. 2015.

MIRANDA, Cybelle Salvador; BELTRÃO, Jane Felipe; HENRIQUE, Márcio. Caminhos e ausências no Patrimônio da saúde em Belém, Pará. Amazônica: Revista de Antropologia (Online), v.2, p.308 - 343, 2013. http://www.periodicos.ufpa.br/index.php/amazonica/article/ view/1496/1903. Acesso em 10 jun 2016. 
MIRANDA, Cybelle Salvador. Memória da assistência à Saúde em Belém-PA: Arquitetura como documento. I Encontro Nacional de Pós-Graduação e Pesquisa em Arquitetura e Urbanismo. Anais...Rio de Janeiro: PROURB, 2010. Disponível em: http://www.anparq.org.br/ dvd-enanparq/simposios/15/15-11-2-SP.pdf. Acesso em: 10 mar. 2014.

MIRANDA, Cybelle Salvador. Itinerários da saúde na Belém colonial e imperial. Anais do III ENANPARQ Arquitetura cidade e projeto: uma construção coletiva. São Paulo: Universidade Presbiteriana Mackenzie, 2014. v.1. p.1 - 16.

MIRANDA, Cybelle Salvador. Saúde e arquitetura em diálogo com Charles Jencks. Drops (São Paulo). v.1, p.1 - 3, 2016.

MONTEIRO, Marcia Rocha; ANDRADE, F. A. G. A Saúde Pública em Alagoas no Brasil Império. Caminhos e Descaminhos. Maceió: Edufal, 2013.

MONTEIRO, Marcia Rocha; NEDER FILHA, Christina Ribeiro. "O hospital e o processo histórico da hospitalização". p. 352-356. O Mundo da Saúde São Paulo (CUSC. Impresso), 2003.

MONTEIRO, Marcia Rocha. "Homens da cana e hospitais do açúcar: uma arquitetura da saúde no Estado Novo". História, Ciências, Saúde - Manguinhos, Rio de Janeiro, v.18, supl.1, dez. 2011, p.67-94.

MONTEIRO, Marcia Rocha. Hospital do Açúcar de Alagoas: arquitetura e assistência à saúde - 50 anos de História. Maceió: EDUFAL, 2015.

SANGLARD, Gisele. "A construção dos espaços de cura no Brasil: entre a Caridade e a medicalização". Revista Esboços, no 16, 2006. https://periodicos.ufsc.br/index.php/esbocos/ article/viewFile/119/166. Acesso em 22 abr 2016.

VIECELI, Ana Paula. A casa e o cais: disjunção da arquitetura no encontro com os lugares da loucura. Anais do IV ENANPARQ, Estado da Arte. Porto Alegre, 25-29 julho 2016 [recurso eletrônico] / Organização: Claudia Costa Cabral, Carlos Eduardo Comas. Porto Alegre: PROPAR/UFRGS, 2016. [ISSN 2358-6214] 